\title{
Extension of Sender Node Battery Extra Availability in Ubicomp with Location-Aware MANET Transmission Compared to Direct Node-To-Node Transmission.
}

\author{
M. Kaleem GALAMALI, Assoc. Prof Nawaz MOHAMUDALLY
}

\begin{abstract}
The field of location-tracking in mobile environments is of utmost necessity and justifies the research investments put in it [1-10] with correspondingly commendable output. With progresses in ubicomp happening, several questions will crop up and whose answers depend on components not yet developed and hence empirical supports to answer these questions may serve as welcome starting points. A previous such study was undertaken to find trends of energy savings achievable by applying location-aware direct Node-ToNode (NTN) transmission strategies [2]. Another study was conducted to model the trends of sender energy savings (SES) achievable in location-aware MANET transmission [14] from the perspective of user nodes being freed from routing tasks of other user's transmissions, i.e. MANET nodes are supplied as infrastructure.
\end{abstract}

Following these two studies [2, 14], the next level of research is laid as: "By what extra amount can the sender nodes' battery availability be extended in location-aware ubicomp MANET transmission compared to direct NodeTo-Node transmission? How does this extra amount vary over varying node numbers in a ubicomp topography?

The results of this study can serve towards better architecture formulations and alleviation of maintenance procedures required for ubicomp. This study follows from previous ones [1-63]

Key terms: Ubicomp- Ubiquitous Computing, MAUCMobile and Ubiquitous Computing, CBR- Constant Bit Rate, MANET- Mobile Adhoc Network, NTN- Node-To-Node, ESEnergy Savings, SES- Sender ES, SLNTNES- Sender Less NTN ES, EC-Energy consumed, SLNTNEC- Sender Less NTN EC, BAEF- Battery Availability Extension Factor, MBAEF- Mean BAEF.

M. Kaleem GALAMALI,

University of Technology Mauritius (student) Mauritius

Assoc. Prof Nawaz Mohamudally University of Technology Mauritius, Mauritius

\section{Introduction}

Understanding the trends of energy consumption and energy savings in ubicomp is of crucial importance for future architecture design. Achieving better hardware batteries will not be so useful if appropriate methods of using them are not well devised. Such methods also include algorithmic methods prone to extend their availability or uptime, one of which is application of location awareness in transmission strategies. Two such strategies were studied formerly from an empirical perspective: one was direct Node-To-Node transmission at exact location awareness [2] and another one was MANET transmission with MANET route nodes supplied as infrastructure [16].

Location-awareness feature requires continual update of location information. The granularity or exactness of this location information varies as per technology used. Current levels of technology, however, operate at overly high overheads to obtain high refresh rates, which also has implications on energy needs. It still remains that simulation models are important to delimit bounds of achievements in this research direction, assuming that the ability to channel exact location information into transmission strategies is very achievable. Following the two strategies of transmission mentioned in previous paragraph, the logical probing that crops up is to experimentally bound the extra energy savings achievable in MANET, with MANET route nodes supplied as infrastructure, compared to direct Node-To-Node transmission. The results of such a study will subsequently serve towards enhancement of ubicomp architectures and decide correct channelling of resources needed.

The key contributions of this paper is firstly, the extension of the simple mathematical method, introduced previously [10-13], for calculating the extra amount of savings achievable by sender nodes in MANETs with Route nodes supplied as infrastructure compared to direct node-to-node transmission, with the application of location-aware transmission. Secondly, model of trend of this extra amount varying over different node numbers in a ubicomp topography of $300 \times 300 \mathrm{~m}^{2}$ is established. The rest of this paper is organised as follows: section 2- Experimental Set-up used, section 3- Results Obtained, section 4Conclusion and References.

\section{Experimental Set-Up Used.}

The same experimental design used in previous paper [10] and referred to in another previous papers [62, 63] is re-used here. 
Metric concerned for this set of experiment is SLNTNES [16].

\section{Results Obtained.}

The study here is split into four subsections: SLNTNES Minimum BAEF (Min_BAEF), SLNTNES Mean BAEF (MBAEF), SLNTNES Maximum BAEF (Max_BAEF) and certain critical values obtainable. The work is basically some further processing applied over certain results obtained previously. Floating points Values instead of integers, are used to get exact results.

\subsection{SLNTNES Min BAEF}

This section follows from section 3.1 in previous paper [48], i.e. SLNTNES critical value 1, representing smallest value of SLNTNES reached. All SLNTNES values obtained here lie at 0 throughout. Minimum SLNTNES is obtained in a situation of maximum value of sender less node-to-node energy consumption (SLNTNEC). SLNTNES Min_BAEF is computed as:

Max_SLNTNEC $=100.00-($ Min_SLNTNES $)$

SLNTNES_Min_BAEF $=100.00 /$ (Max_SLNTNEC)

Since Min_SLNTNES equals 0, i.e. a value between 0.5 and +0.5 , Min_BAEF will vary between 0.995024 875 and 1.005025126 , i.e. remains at a rounded value of 1.00 for all node numbers. This value depicts that at worst case, nodes' batteries availability do not benefit from any extra extension.

\subsection{SLNTNES MBAEF}

This section follows from section 2.3 in previous paper [32], i.e. SLNTNES parameter c of SLNTNES equation of trend. Corresponding Modal BAEF is computed as: Modal_SLNTNEC $=100.00-($ Modal SLNTNES $)$ SLNTNES Modal BAEF $=100.00 /$ (Modal SLNTNEC)

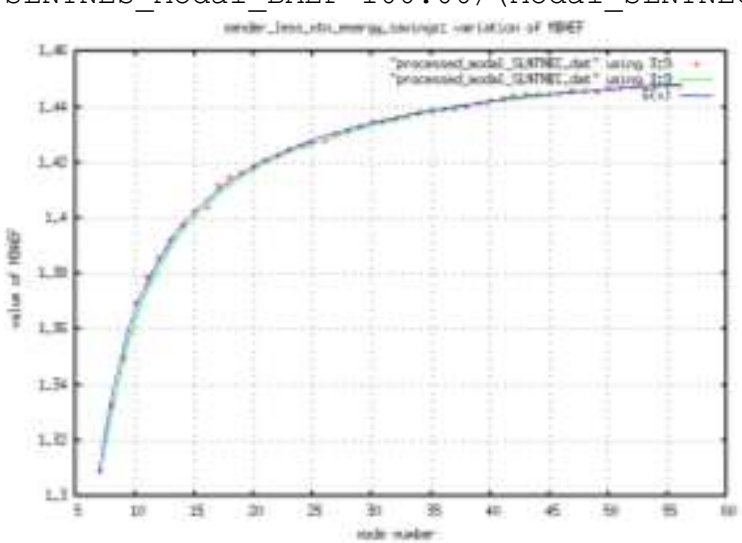

Figure 1: SLNTNES MBAEF

The values of SLNTNES_Modal_BAEF were computed for node numbers 7 until 56 and corresponding plot is given in figure 1.

The equation of best fit here, G(x), has also followed similar computation over $\mathrm{F}(\mathrm{x})$ obtained in section 2.3 of

previous paper [32], retaining the values of parameters $\mathrm{a}, \mathrm{b}, \mathrm{c}$ and $\mathrm{f}$.

$$
\begin{aligned}
& F(x)=\left(a / x^{f}\right) \star \log (b * x+c) \\
& G(x)=100.00 /(100.00-F(x))
\end{aligned}
$$

\subsection{SLNTNES Max BAEF.}

This section follows from section 3.2 in previous paper [48], i.e. SLNTNES critical value 2 representing highest value of SLNTNES reached. Maximum SLNTNES is obtained corresponding to minimum sender less Node-to-Node Energy consumed, SLNTNEC. Max_BAEF is computed as follows:

$$
\begin{aligned}
& \text { Min_SLNTNEC }=100.00-(\text { Max_SLNTNES) } \\
& \text { SLNTNES_Max_BAEF }=100.00 / \text { (Min_SLNTNEC) }
\end{aligned}
$$

The values of SLNTNES Max_BAEF were computed for node numbers 7 until 56 and corresponding plot is given in figure 2 .

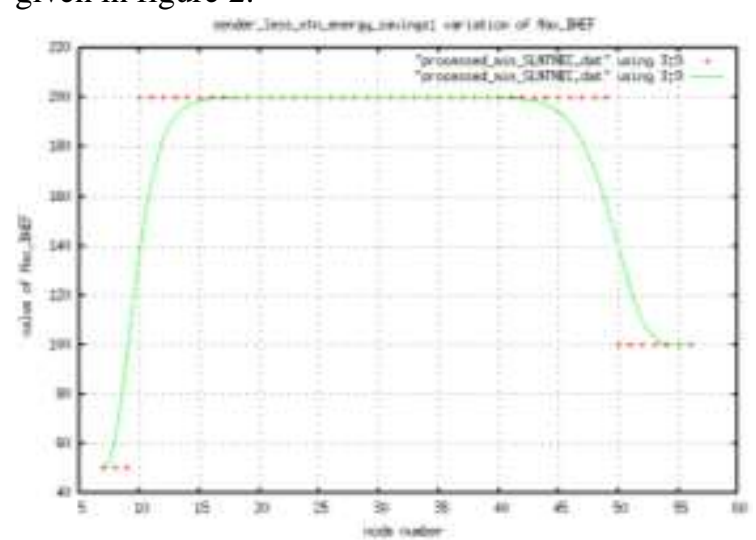

Figure 2: SLNTNES Max_BAEF Trend

Three ranges are visible in the plot. The applicable equations are:

$$
G(x)=\left\{\begin{array}{rr}
50 & 7 \leq x \leq 9 \\
200 & 10 \leq x \leq 49 \\
100 & x \geq 50
\end{array}\right.
$$

\subsection{Certain OES BAEF Critical Values.}

Four critical values have been identified as presented in Table 1, which correspond to certain critical values studied previously [48]. Colum headings are: $\mathrm{C} 1 \rightarrow$ SLNTNES BAEF critical value, $\mathrm{C} 2 \rightarrow$ Meaning of SLNTNES BAEF critical value, $\mathrm{C} 3 \rightarrow$ section in previous paper [48] the SLNTNES BAEF critical value corresponds to.

\begin{tabular}{|c|l|l|}
\hline C1 & C2 & C3 \\
\hline 1 & \% nodes reaching Max_BAEF. & 3.3 \\
\hline 2 & \% nodes reaching MBAEF. & 3.5 \\
\hline 3 & \% nodes with BAEF < MBAEF & 3.6 \\
\hline 4 & \% nodes with BAEF > MBAEF & 3.7 \\
\hline
\end{tabular}

Table 1: SLNTNES BAEF Critical Values

\section{Conclusion.}


This study has probed into the extension of a mathematical method for predicting the extra proportion to which battery availability of sender nodes present in a ubicomp topography of $300 \times 300 \mathrm{~m}^{2}$ could be extended using MANETs, with MANET route nodes supplied as infrastructure, compared to direct Node-ToNode transmission, both using exact location-aware transmission strategies. The method introduced formerly [10] and extended here, has been applied over results put forward in previous papers $[16,32,48]$. This study complements to the study of ubicomp components from the broad view of software engineering. It also provides for supplementary components for prediction and measuring reliability of ubicomp environment. Moreover, in this probing, certain new metrics developed previously [10] to strengthen models in ubicomp and more judiciously fashion the architecture of ubicomp, are elaborated.

This study has been devised over previous empirical studies done in simulator software NS-2 over Linux. Gnuplot is the tool used for graphical analysis. Floating point calculations have been used to obtain accurate answers. This study was aimed at providing value of $\mathrm{BAEF}$ in an unbiased mathematical perspective. The values and trends obtained have not been subjected to interpretations of being $\mathrm{good} / \mathrm{bad}$, workable/unworkable or efficient/inefficient. Designers using these models will determine their interpretations as they apply them properly in their topographies.

Further work identified remains refinement of the model and equations of trend obtained and subjecting the metrics defined to more rigorous software engineering approaches.

\section{References}

[1] M. Kaleem GALAMALI, Assoc. Prof Nawaz MOHAMUDALLY, Towards Dependable Pervasive Systems-A Position and Vision Paper, CEET 2014

[2] M. Kaleem GALAMALI, Assoc. Prof Nawaz MOHAMUDALLY, Model of Energy Savings achievable with Location-aware Node-to-Node Transmission in UbiComp, CEET 2014

[3] M. Kaleem GALAMALI, Assoc. Prof Nawaz MOHAMUDALLY, Model of Energy Savings achievable with Location-aware Node-to-Node Transmission in UbiComp Using Location Refresh Intervals, CEET 2014

[4] M. Kaleem GALAMALI, Assoc. Prof Nawaz MOHAMUDALLY, Model of Energy Savings achievable with Location-aware Transmission in UbiComp Using Relays, CEET 2014

[5] M. Kaleem GALAMALI, Assoc. Prof Nawaz MOHAMUDALLY, Mathematical modeling of need of exact number of relays to ensure seamless mobility in mobile computing, CEET 2014

[6] M. Kaleem GALAMALI, Assoc. Prof Nawaz MOHAMUDALLY, Modelling of need for multiple relays for ensuring seamless mobility, CEET 2014
M. Kaleem GALAMALI, Assoc. Prof Nawaz MOHAMUDALLY, Investigation of prominence of placements of relays in a ubicomp topography,

[8] M. Kaleem GALAMALI, Assoc. Prof Nawaz MOHAMUDALLY, Model of energy savings achievable with location-aware transmission in ubicomp using optimised number of relays.

[9] M. Kaleem GALAMALI, Assoc. Prof Nawaz MOHAMUDALLY, Investigation of Prominence of Placements of Optimised Number of Relays in a Ubicomp Topography using Location-Aware Transmission, CEET 2015.

[10] M. Kaleem GALAMALI, Assoc. Prof Nawaz MOHAMUDALLY, Extending Node Battery Availability in Ubicomp with Location-Aware Transmission, CEET 2015.

[11] M. Kaleem GALAMALI, Assoc. Prof Nawaz MOHAMUDALLY, Extending Node Battery Availability in Ubicomp with Location-Aware Transmission using Location Refresh Intervals, CEET 2015.

[12] M. Kaleem GALAMALI, Assoc. Prof Nawaz MOHAMUDALLY, Extending Node Battery Availability in Ubicomp with Location-Aware Transmission using Uniformly Placed Relays, CEET 2015.

[13] M. Kaleem GALAMALI, Assoc. Prof Nawaz MOHAMUDALLY, Extending Node Battery Availability in Ubicomp with Location-Aware Transmission Using Optimally Placed Relays, CEET 2015.

[14] M. Kaleem GALAMALI, Assoc. Prof Nawaz MOHAMUDALLY, Model of Sender Node Energy Savings Achievable with Location-Aware MANET Transmission in Ubicomp. ACCN 2016

[15] M. Kaleem GALAMALI, Assoc. Prof Nawaz MOHAMUDALLY, Model of Overall Node Energy Savings Achievable with Location-Aware MANET Transmission in Ubicomp. ACCN 2016

[16] M. Kaleem GALAMALI, Assoc. Prof Nawaz MOHAMUDALLY, Model of Sender Node Extra Energy Savings Achievable in MANET Against Direct Node-to-Node Transmission Using Location-Aware Transmission in Ubicomp. ACCN 2016

[17] M. Kaleem GALAMALI, Assoc. Prof Nawaz MOHAMUDALLY, Model of Overall Node Extra Energy Savings Achievable in MANET against Direct Node-to-Node Transmission Using Location-Aware Transmission in Ubicomp. ACCN 2016

[18] M. Kaleem GALAMALI, Assoc. Prof Nawaz MOHAMUDALLY, Model of Energy Consumption Ratio Achievable in MANET Using Location-Aware Transmission in Ubicomp. ACCN 2016

[19] M. Kaleem GALAMALI, Assoc. Prof Nawaz MOHAMUDALLY, Model of Minimum Energy Consumption Ratio Achievable in MANET Using LocationAware Transmission in Ubicomp. ACCN 2016

[20] M. Kaleem GALAMALI, Assoc. Prof Nawaz MOHAMUDALLY, Model of Maximum Energy Consumption Ratio Achievable in MANET Using LocationAware Transmission in Ubicomp. ACCN 2016

[21] M. Kaleem GALAMALI, Assoc. Prof Nawaz MOHAMUDALLY, Model of Overall Energy Consumption Fairness Ratio Achievable in MANET Using Location-Aware Transmission in Ubicomp. ACCN 2016

[22] M. Kaleem GALAMALI, Assoc. Prof Nawaz MOHAMUDALLY, Model of Overall Energy Consumption Fairness Proportion Achievable in MANET Using LocationAware Transmission for Ubicomp, CEET 2016

[23] M. Kaleem GALAMALI, Assoc. Prof Nawaz MOHAMUDALLY, Model of Minimum Fairness Proportion Achievable in MANET Using Location-Aware Transmission for Ubicomp, CEET 2016

[24] M. Kaleem GALAMALI, Assoc. Prof Nawaz MOHAMUDALLY, Model of Maximum Fairness Proportion Achievable in MANET Using Location-Aware Transmission for Ubicomp, CEET 2016

[25] M. Kaleem GALAMALI, Assoc. Prof Nawaz MOHAMUDALLY, Model of Sender Fairness Proportion Achievable in MANET Using Location-Aware Transmission for Ubicomp, CEET 2016

[26] M. Kaleem GALAMALI, Assoc. Prof Nawaz MOHAMUDALLY, Model of Distance Travelled by packets in MANETs using Location-Aware Transmission for 
Ubicomp, CEET 2016

[27] M. Kaleem GALAMALI, Assoc. Prof Nawaz MOHAMUDALLY, Model of Maximum CBR Distance Travelled by packets in MANETs using Location-Aware Transmission for Ubicomp, CEET 2016

[28] M. Kaleem GALAMALI, Assoc. Prof Nawaz MOHAMUDALLY, Model of Minimum CBR Distance Travelled by packets in MANETs using Location-Aware Transmission for Ubicomp, CEET 2016

[29] M. Kaleem GALAMALI, Assoc. Prof Nawaz MOHAMUDALLY, Model of Range CBR Distance Experienced by Transmissions in MANETs using LocationAware Transmission for Ubicomp, CEET 2016

[30] M. Kaleem GALAMALI, Assoc. Prof Nawaz MOHAMUDALLY, Trend Analyses of Parameters of Equations for Sender Node Energy Savings Achievable in ubicomp MANETs using Location-Aware Transmission, ACCN 2017.

[31] M. Kaleem GALAMALI, Assoc. Prof Nawaz MOHAMUDALLY, Trend Analyses of Parameters of Equations for Overall Node Energy Savings Achievable in ubicomp MANETs using Location-Aware Transmission, ACCN 2017.

[32] M. Kaleem GALAMALI, Assoc. Prof Nawaz MOHAMUDALLY, Trend Analyses of Parameters of Equations for Sender Node Extra Energy Savings Achievable in MANET against Direct Node-to-Node Location-Aware Transmission, ACCN 2017.

[33] M. Kaleem GALAMALI, Assoc. Prof Nawaz MOHAMUDALLY, Trend Analyses of Parameters of Equations for Overall Nodes Extra Energy Savings Achievable in MANET against Direct Node-to-Node Location-Aware Transmission, ACCN 2017.

[34] M. Kaleem GALAMALI, Assoc. Prof Nawaz MOHAMUDALLY, Trend Analyses of Parameters of Equations for Energy Consumption Ratio Achievable in Ubicomp MANET Using Location-Aware Transmission, ACCN 2017.

[35] M. Kaleem GALAMALI, Assoc. Prof Nawaz MOHAMUDALLY, Trend Analyses of Parameters of Equations for Minimum Energy Consumption Ratio Achievable in Ubicomp MANETs Using Location-Aware Transmission, ACCN 2017.

[36] M Kaleem GALAMALI, Assoc Prof Nawaz MOHAMUDALLY, Trend Analyses of Parameters of Equations for Maximum Energy Consumption Ratio Achievable in Ubicomp MANETs Using Location-Aware Transmission, ACCN 2017.

[37] M. Kaleem GALAMALI, Assoc. Prof Nawaz MOHAMUDALLY, Trend Analyses of Parameters of Equations for Overall Fairness Ratio Achievable in Ubicomp MANETs Using Location-Aware Transmission, ACCN 2017.

[38] M. Kaleem GALAMALI, Assoc. Prof Nawaz MOHAMUDALLY, Trend Analyses of Parameters of Equations for Energy Consumption Fairness Proportion Achievable in Ubicomp MANETs Using Location-Aware Transmission, CEET 2017

[39] M. Kaleem GALAMALI, Assoc. Prof Nawaz MOHAMUDALLY, Trend Analyses of Parameters of Equations for Minimum Fairness Proportion Achievable in Ubicomp MANETs Using Location-Aware Transmission, CEET 2017

[40] M. Kaleem GALAMALI, Assoc. Prof Nawaz MOHAMUDALLY, Trend Analyses of Parameters of Equations for Maximum Fairness Proportion Achievable in Ubicomp MANETs Using Location-Aware Transmission, CEET 2017

[41] M. Kaleem GALAMALI, Assoc. Prof Nawaz MOHAMUDALLY, Trend Analyses of Parameters of Equations for Sender Fairness Proportion Achievable in Ubicomp MANETs Using Location-Aware Transmission, CEET 2017

[42] M. Kaleem GALAMALI, Assoc. Prof Nawaz MOHAMUDALLY, Trend Analyses of Parameters of Equations for Packets Per Distance Achievable in Ubicomp MANETs Using Location-Aware Transmission, CEET 2017

[43] M. Kaleem GALAMALI, Assoc. Prof Nawaz MOHAMUDALLY, Trend Analyses of Parameters of Equations for Maximum CBR Distance Achievable in Ubicomp MANETs Using Location-Aware Transmission, CEET 2017
[44] M. Kaleem GALAMALI, Assoc. Prof Nawaz MOHAMUDALLY, Trend Analyses of Parameters of Equations for Minimum CBR Distance Achievable in Ubicomp MANETs Using Location-Aware Transmission, CEET 2017

[45] M. Kaleem GALAMALI, Assoc. Prof Nawaz MOHAMUDALLY, Trend Analyses of Parameters of Equations for Range CBR Distance Achievable in Ubicomp MANETs Using Location-Aware Transmission, CEET 2017

[46] M. Kaleem GALAMALI, Assoc. Prof Nawaz MOHAMUDALLY, Trend Analyses of Critical Values Obtained for Sender Node Energy Savings Achievable in Ubicomp MANETs Using Location-Aware Transmission, CEET 2017

[47] M. Kaleem GALAMALI, Assoc. Prof Nawaz MOHAMUDALLY, Trend Analyses of Critical Values Obtained for Overall Node Energy Savings Achievable in Ubicomp MANETs Using Location-Aware Transmission, CEET 2017

[48] M. Kaleem GALAMALI, Assoc. Prof Nawaz MOHAMUDALLY, Trend Analyses of Critical Values Obtained for Sender Node Extra Energy Savings Achievable in Ubicomp MANET Against Direct Node-to-Node LocationAware Transmission, CEET 2017

[49] M. Kaleem GALAMALI, Assoc. Prof Nawaz MOHAMUDALLY, Trend Analyses of Critical Values Obtained for Overall Nodes Extra Energy Savings Achievable in Ubicomp MANET Against Direct Node-to-Node LocationAware Transmission, CEET 2017

[50] M. Kaleem GALAMALI, Assoc. Prof Nawaz MOHAMUDALLY, Trend Analyses of Critical Values Obtained for Energy Consumption Ratio Achievable in Ubicomp MANETs Using Location-Aware Transmission Strategies, CEET 2017

[51] M. Kaleem GALAMALI, Assoc. Prof Nawaz MOHAMUDALLY, Trend Analyses of Critical Values Obtained for Minimum Energy Consumption Ratio Achievable in Ubicomp MANETs Using Location-Aware Transmission Strategies, CEET 2017

[52] M. Kaleem GALAMALI, Assoc. Prof Nawaz MOHAMUDALLY, Trend Analyses of Critical Values Obtained for Maximum Energy Consumption Ratio Achievable in Ubicomp MANETs Using Location-Aware Transmission Strategies, CEET 2017

[53] M. Kaleem GALAMALI, Assoc. Prof Nawaz MOHAMUDALLY, Trend Analyses of Critical Values Obtained for Overall Fairness Ratio Achievable in Ubicomp MANETs Using Location-Aware Transmission Strategies, CEET 2017

[54] M. Kaleem GALAMALI, Assoc. Prof Nawaz MOHAMUDALLY, Trend Analyses of Critical Values Obtained for Energy Consumption Fairness Proportion Achievable in Ubicomp MANETs Using Location-Aware Transmission Strategies, ACCN 2017.

[55] M. Kaleem GALAMALI, Assoc. Prof Nawaz MOHAMUDALLY, Trend Analyses of Critical Values Obtained for Minimum Fairness Proportion Achievable in Ubicomp MANETs Using Location-Aware Transmission Strategies, ACCN 2017.

[56] M. Kaleem GALAMALI, Assoc. Prof Nawaz MOHAMUDALLY, Trend Analyses of Critical Values Obtained for Maximum Fairness Proportion Achievable in Ubicomp MANETs Using Location-Aware Transmission Strategies, ACCN 2017.

[57] M. Kaleem GALAMALI, Assoc Prof Nawaz MOHAMUDALLY, Trend Analyses of Critical Values Obtained for Sender Fairness Proportion Achievable in Ubicomp MANETs Using Location-Aware Transmission Strategies, ACCN 2017.

[58] M. Kaleem GALAMALI, Assoc. Prof Nawaz MOHAMUDALLY, Trend Analyses of Critical Values Obtained for Packets Per Distance Achievable in Ubicomp MANETs Using Location-Aware Transmission Strategies, ACCN 2017.

[59] M. Kaleem GALAMALI, Assoc. Prof Nawaz MOHAMUDALLY, Trend Analyses of Critical Values Obtained for Maximum CBR Distance Achievable in Ubicomp MANETs Using Location-Aware Transmission Strategies, ACCN 2017.

[60] M. Kaleem GALAMALI, Assoc. Prof Nawaz MOHAMUDALLY, Trend Analyses of Critical Values Obtained for Minimum CBR Distance Achievable in Ubicomp MANETs Using Location-Aware Transmission Strategies, ACCN 2017.

[61] M. Kaleem GALAMALI, Assoc. Prof Nawaz 
MOHAMUDALLY, Trend Analyses of Critical Values Obtained for Range CBR Distance Achievable in Ubicomp MANETs Using Location-Aware Transmission Strategies, ACCN 2017.

[62] M. Kaleem GALAMALI, Assoc. Prof Nawaz MOHAMUDALLY, Extending Sender Node Battery Availability in Ubicomp with Location-Aware MANET Transmission, ACCN 2017.

[63] M. Kaleem GALAMALI, Assoc. Prof Nawaz MOHAMUDALLY, Extending Overall Node Battery Availability in Ubicomp with Location-Aware MANET Transmission, ACCN 2017.

[64] Markus Bylund and Zary Segall, Towards seamless mobility with personal servers, 2004

[65] Masugi Inoue, Mikio Hasegawa, Nobuo Ryoki and Hiroyuki Morikawa, Context-Based Seamless Network and Application Control, 2004

[66] Xiang Song, Umakishore Ramachandran, MobiGo: A Middleware for Seamless Mobility, College of Computing Georgia Institute of Technology, Atlanta, GA, USA, August 2007

[67] Budzisz, Ferrús, R., Brunstrom A., Grinnemo, K, Fracchia, R., Galante, G., and Casadevall, F. Towards transport-layer mobility: Evolution of SCTP multihoming, March 2008

[68] Paul Dourish \& Genevieve Bell, Divining a digital future, 2011.

[69] Xiang Song, Seamless Mobility In Ubiquitous Computing Environments, PhD Thesis, Georgia Institute of Technology, Aug 2008

[70] Kevin O Mahony, Jian Liang, Kieran Delaney, User-Centric Personalization and Autonomous Reconfiguration Across Ubiquitous Computing Environments, NIMBUS Centre Cork Institute of Technology, Cork, Ireland, UBICOMM 2012

[71] Pablo Vidales, Seamless mobility in $4 \mathrm{G}$ systems, Technical Report, University of Cambridge, Computer Laboratory, Number 656, November 2005

[72] João Pedro Sousa and David Garlan, Aura: An Architectural Framework for User Mobility in Ubiquitous Computing Environments, School of Computer Science, Carnegie Mellon University, USA, August 2002

[73] Dennis Lupiana, Ciaran O'Driscoll, Fredrick Mtenzi, Defining Smart Space in the Context of Ubiquitous Computing, Dublin Institute of Technology, Ireland, Special Issue on ICIT 2009 Conference - Web and Agent Systems, 2009

[74] N.S.V.Shet1, Prof.K.Chandrasekaran2 and Prof. K.C.Shet3, WAP Based Seamless Roaming In Urban Environment with Wise Handoff Technique, International Journal of UbiComp (IJU), Vol.1, No.4, October 2010

[75] Yipeng Yu Dan He Weidong Hua Shijian Li Yu Qi Yueming Wang Gang Pan, FlyingBuddy2: A Brain-controlled Assistant for the Handicapped, Zhejiang University, UbiComp'12, September 5-8, 2012.

[76] Jing Su, James Scott, Pan Hui, Jon Crowcroft, Eyal de Lara Christophe Diot, Ashvin Goel, Meng How Lim, and Eben Upton, Haggle: Seamless Networking for Mobile Applications, 2007

[77] Rui Han, Moustafa M. Ghanem, Li Guo, Yike Guo*, Michelle Osmond, Enabling cost-aware and adaptive elasticity of multi-tier cloud applications, Future Generation Computer Systems, 2012

[78] Byrav Ramamurthy, K. K. Ramakrishnan, Rakesh K. Sinha, Cost and Reliability Considerations in Designing the NextGeneration IP over WDM Backbone Networks, 2012

[79] Bhavish Aggarwal, Aditya Akella, Ashok Anand, Athula Balachandran, Pushkar Chitnis, Chitra Muthukrishnan, Ram Ramjee and George Varghese, EndRE: An End-System Redundancy Elimination Service for Enterprises, NSDI 2010, San Jose, CA

[80] Ashok Anand, Vyas Sekar and Aditya Akella, SmartRE: An Architecture for Coordinated Network-wide Redundancy Elimination, SIGCOMM 2009, Barcelona, Spain

[81] John Breeden II, "Smart-phone battery life could double without better batteries", Nov 14, 2012

[82] Andy Boxall, "When will your phone battery last as long as your kindle", December 5, 2012.

[83] Imielinski, T. and Navas, J.C. (1999). GPS-based geographic addressing, routing, and resource discovery. Comms. ACM, Vol. 42, No. 4, pp. 86-92.

[84] Hightower, J. and Borriello, G. (2001). Location Systems for Ubiquitous Computing. IEEE Computer, Vol. 34, No. 8, August, pp. 57-66.

[85] Harter, A., Hopper, A., Steggles, P., Ward, A. and Webster, P.
(2002). The Anatomy of a Context-Aware Application. Wireless Networks, Vol. 8, No. 2-3, Mar-May, pp. 187-197.

[86] Hightower, J., Brumitt, B. and Borriello, G. (2002). The Location Stack: A Layered Model for Location in Ubiquitous Computing. Proceedings of the 4th IEEE Workshop on Mobile Computing Systems \& Applications (WMCSA 2002), Callicoon, NY, USA, June, pp. 22-28.

[87] Graumann, D., Lara, W., Hightower, J. and Borriello, G. (2003) Real-world implementation of the Location Stack: The Universal Location Framework. Proceedings of the 5th IEEE Workshop on Mobile Computing Systems \& Applications (WMCSA 2003), Monterey, CA, USA, October, pp. 122-128.

[88] Ko, Y., \& Vaidya, N. H. (2000). Location-aided routing (LAR) in mobile ad hoc networks. Wireless Networks, 6(4), 307-321.

[89] Liao, W.-H., Tseng, Y.-C., \& Sheu, J.-P. (2001). GRID: a fully location-aware routing protocol for mobile ad hoc networks. Telecommunication Systems, 18(1), 37-60.

[90] Kuhn, F., Wattenhofer, R., Zhang, Y., \& Zollinger, A. (2003). Geometric ad-hoc routing: of theory and practice. In Proceedings of the ACM (PODC'03) (pp. 63-72).

[91] Jiang, X., \& Camp, T. (2002). Review of geocasting protocols for a mobile ad hoc network. In Proceedings of the Grace Hopper Celebration (GHC).

[92] Xu, Y., Heidemann, J., \& Estrin, D. (2001). Geographyinformed energy conservation for adhoc routing. In Proceedings of the ACM/IEEE (MOBICOM'01) (pp. 70-84).

[93] Hu, Y.-C., Perrig, A., \& Johnson, D. (2003). Packet leashes: a defense against wormhole attacks in wireless ad hoc networks. In Proceedings of the INFOCOM' 03 (pp. 1976-1986).

[94] Patwari, N., Hero III, A. O., Perkins, M., Correal, N. S., \& O'Dea, R. J. (2003). Relative location estimation in wireless sensor networks. IEEE Transactions on Signal Processing, 51(8), 2137-2148.

[95] Baldauf, M., Dustdar, S., \& Rosenberg, F. (2007). A Survey on Context Aware Systems. International Journal of Ad Hoc and Ubiquitous Computing, Inderscience Publishers. forthcoming. Pre-print from: http://www.vitalab.tuwien.ac.at/ florian/papers/ijahuc2007.pdf

[96] Hong, D., Chiu, D.K.W., \& Shen, V.Y. (2005). Requirements elicitation for the design of context-aware applications in a ubiquitous environment. In Proceedings of ICEC'05 (pp. 590-596).

[97] Neeraj Tantubay, Dinesh Ratan Gautam and Mukesh Kumar Dhariwal, A Review of Power Conservation in Wireless Mobile Ad hoc Network (MANET)", International Journal of computer Science Issues, Vol 8, Issue 4, No 1, July 2011.

[98] Wenrui Zhao, Mostafa Ammar and Ellen Zegura, "A Message Ferrying Approach for Data Delivery in Sparse Mobile Ad Hoc Networks", MobiHoc'04, May 24-26, 2004, Roppongi, Japan.

[99] Sgroi et al., "Designing Wireless Protocols: Methodology and Applications, February 2000.

[100] Gyula et al., "Simulation-based optimization of communication protocols for large-scale wireless sensor networks", 10 Oct 2002

[101] Rao and Sharma, "Cross Layer Protocols For Multimedia Transmission in Wireless Networks", June 2012

[102] Herms et al, "Realism in Design and Evaluation of Wireless Routing Protocols", 2007.

About Author (s):

Associate Professor Nawaz Mohamudally works at University of Technology, Mauritius (UTM) and has undertaken supervision of $\mathrm{MPhil} / \mathrm{PhD}$ Students for many years.

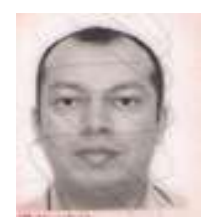

M. Kaleem Galamali is a part-time student (achieved M Phil Transfer on 28.10.2014, currently PhD student) at UTM under supervision of A.P. Nawaz Mohamudally. 